\title{
Työsuojelun vaikuttavuutta estävät ja edistävät tekijät maatiloilla
}

\author{
Tiina E.A. Mattila ${ }^{1)}$, Kim O. Kaustell ${ }^{1)}$, Risto H. Rautiainen ${ }^{2)}$ \\ 1) Maa- ja elintarviketalouden tutkimuskeskus, Vakolantie 5503400 Vihti. \\ tiina.mattila@mtt.fi,kim.kaustell@mtt.fi \\ ${ }^{2)}$ Department of Environmental, Agricultural, \& Occupational Health, College of Public Health, \\ Swanson Hall 3058, 985110 Nebraska Medical Center, Omaha, NE 68198-5110 USA. \\ rrautiainen@unmc.edu
}

\section{Tiivistelmä}

Useiden tutkimusten mukaan maataloustöissä sattuu edelleen paljon tapaturmia. Tapaturmamäärien vähentämiseksi maatalouteen on kohdistettu monia interventioita eli toimenpiteitä, joilla pyritään vaikuttamaan yksilöiden ja ryhmien terveydentilaan ja käyttäytymiseen. Tutkimukset, joissa on käyty systemaattisesti läpi interventiotutkimusten tuloksia, ovat todenneet, että interventioiden tehokkuudesta tapaturmien vähentämisessä on varsin vähän näyttöä.

Tämän tutkimuksen tavoitteena oli löytää tekijöitä, jotka estävät työturvallisuuden kehittymistä ja huomioon ottoa - sekä toisaalta katalysaattoreita, jotka edistävät turvallisten toimintatapojen ja ratkaisujen yleistymistä ja käyttöönottoa maatiloilla. Erityisesti keskityttiin koneiden ja rakennusten huolto- ja korjaustöiden turvallisuuteen. Tutkimuksessa on viitekehykseksi luotu käsitemalli työturvallisuusinterventioiden komponenteista ja maatilakontekstista. Datankeruussa käytettiin luotainmenetelmää ja haastatteluja. Luotain-menetelmä on otettu yleisesti käyttöön käyttäjätutkimuksissa ja se perustuu koehenkilöiden itsedokumentointeihin.

Tulosten mukaan tiloilla on tunnistettavissa runsaasti erilaisia työturvallisuuskehitystä estäviä tai hidastavia tekijöitä sekä jonkin verran myös työturvallisuutta edistäviä tekijöitä. Hidastavat tekijät liittyivät muun muassa suunnittelun tai toteutuksen monimutkaisuuteen, prioriteetteihin, asenteisiin, työtapoihin, ammattitaitovaatimuksiin, kone- ja rakennuskannan hitaaseen uusiutumiseen sekä pysyviksi muodostuneisiin, "väliaikaisiin” ratkaisuihin. Edistävät tekijät liittyivät muun muassa sopivaan viestintäkanavaan, vahinkotilanteiden tuomaan valppauteen, opiskelussa saatuihin viesteihin, vastuuseen muista työntekijöistä, harrastustoiminnassa opittuihin taitoihin, uusien koneiden ja laitteiden tuomaan inspiraatioon, riittävään työvoimaan tilalla ja henkiseen valmentautumiseen mahdollisten vahinkotilanteiden varalta. Tulokset tulevat tukemaan jatkossa työsuojeluinterventioiden suunnittelua ja muotoilua.

Asiasanat: työsuojelu, interventiot, turvallisuus, tapaturmat, maatalous 


\section{Johdanto}

Tämän tutkimuksen tavoitteena oli tunnistaa tekijöitä, jotka estävät ja hidastavat sekä toisaalta tekijöitä, jotka edistävät turvallisia työtapoja ja turvallisen työympäristön muodostumista maatiloille. Päämääränä on, että näiden esteiden ja katalyyttien tunnistaminen auttaa tulevaisuudessa entistä tehokkaampien työsuojeluinterventioiden kehittämisessä.

Schulte ym. (2003) jakavat interventioiden tietovirran kolmeen osaan: tiedon tuottaminen, tiedon välittäminen ja tiedon käyttö. Tiedon tuottamiseen on käytetty niin Suomessa kuin muuallakin paljon resursseja ja maatilojen työturvallisuusvaaroista on saatavissa runsaasti tietoa (esimerkiksi NASD 2009; Erkki-tietopankki). Tätä tietoa on välitetty viljelijöille monin tavoin yksinkertaisista tiedotteista monipuolisiin työsuojelukampanjoihin. Viimeaikaisten systemaattisten kirjallisuusanalyysien perusteella näyttää kuitenkin siltä, että toistaiseksi ei ole pystytty saamaan kovin hyvää näyttöä siitä, että maatiloille kohdistetut työsuojeluinterventiot olisivat olleet tehokkaita työturvallisuuden parantamisessa (DeRoo \& Rautiainen 2000; Rautiainen ym. 2008). Anyaegbunam (2007) toteaa interventioista, että ollakseen tehokas intervention toimeenpanijoiden on tunnettava kohderyhmä hyvin. Näiden tietojen valossa valitsimme tässä tutkimuksessa käyttäjälähtöisen tutkimusotteen, tavoitteenamme tutkia esteitä ja katalyyttejä, jotka vaikuttavat turvallisuustiedon omaksumiseen ja käyttöönottoon tiloilla.

\section{Aineisto ja menetelmät}

Tutkimuksen keskeisin menetelmä oli Luotain-tutkimus, jonka Mattelmäki (2006) kuvaa väitöskirjassaan. Luotain-tutkimus perustuu kohderyhmän itsedokumentointiin, jota tässä tutkimuksessa täydennettiin ryhmähaastattelujen tyyppisissä aineiston purkutilaisuuksissa. Luotainpaketti koostui tehtäväkuvauksesta, kamerasta, muistiinpanovälineistä ja virikemateriaalista. Sen avulla aktivoitiin koehenkilöitä tunnistamaan vaaran paikkoja, kuvailemaan, miten ja miksi ne ovat muodostuneet ja kertomaan, millä keinoin joitakin vaaran paikkoja on saatu poistettua. Materiaalin keruun pääpaino ei ollut vaarojen listauksessa vaan niiden taustassa ja synnyssä, toimintatavoissa ja toisaalta uudistuksiin johtaneissa impulsseissa. Luotain-itsedokumentointiin osallistui yhdeksän maatalousalan opiskelijaa ja ammattilaista. Dokumentoinnissa pyydettiin keskittymään rakennusten sekä koneiden ja laitteiden huoltoon ja korjaukseen.

Luotaimen lisäksi käytiin yhdellätoista kotieläintilalla, joilla oli ollut tulipalo, ja haastateltiin tilanväkeä. Tulipalo on tällaisilla tiloilla luonnollisesti ollut merkittävä tekijä paloturvallisuuden entistä paremmassa huomioon ottamisessa tuotantoa uudelleen käynnistettäessä. Haastatteluissa mainittiin ja kuvailtiin kuitenkin monia esteitä paloturvallisuutta koskevan tiedon soveltamiselle tilalla.

\section{Tulokset ja tulosten tarkastelu}

Aineiston kerääminen ja analysointi etenivät osin päällekkäin ja aikaisempia tuloksia täydennettiin aina uusilla. Perustan muodostivat viiden ensimmäisen luotaimen tulokset. Niitä täydennettiin haastatteluin ja toisella luotain-erällä. Tässä esitetään osa tuloksista.

\section{Esteitä ja hidasteita työturvallisuuden kehittymiselle}

Pyrittäessä tunnistamaan esteitä ja hidasteita työturvallisuuden kehittymiselle maatiloilla, kietoutuvat taustalla olevat syyt toisiinsa. Analyyttinen 'miksi'-kysymys johtaa siten vain monisäikeisempään selitykseen sille, minkä vuoksi turvallisuustieto ei ole johtanut turvallisempiin työtapoihin tai käytettävissä olevia resursseja ei ole ohjattu turvallisuuden parantamiseen. Esteitä ja hidasteita etsittäessä on tehokkaampaa pyrkiä kokoamaan viljelijöiden toiminnan taustalla vaikuttavia motivaatiotekijöitä.

Koneiden ja laitteiden kehityksen tarkoituksena on edistää työturvallisuutta, mutta se ei silti takaa, että työ muuttuisi turvallisemmaksi. Vakiintuneet tavat ja tottumukset voivat siirtyä uuteen ympäristöön ja romuttaa turvallisuuspotentiaalia. Koehenkilöt kertoivat esimerkiksi, että vanhan traktorin ohjaamon lattialla olleita työkaluja ja varusteita säilytettiin edelleen uuden traktorin lattialla, vaikka uudessa traktorissa olisi tarkoituksenmukaisia varustelaatikoita, joissa tavaroita voisi turvallisemmin säilyttää.

Usein mainittu vaara koneiden ylläpidossa oli traktorin etukuormaajan alle meneminen öljyn tms. tarkistamisen yhteydessä. Koehenkilöt kertoivat asian taustaksi, että öljyä on hankala tai joissain vanhoissa traktoreissa mahdoton tarkistaa, jos etukuormain on alhaalla. Tästä johtuen on tullut tavaksi jättää etukuormaaja yläasentoon konetyön päätteeksi. Näin öljyn voi helposti tarkistaa koneen oltua 
pysähdyksissä, ja liikkeellelähtö sujuu ripeästi. Vanha työtapa siirtyy tässäkin hyvin helposti uuden traktorin käyttörutiineihin. Uudemmissa traktoreissa öljyn tarkistaminen kuitenkin olisi mahdollista, vaikka etukuormaaja olisikin alhaalla, tai ainakaan sen alle ei ole pakko mennä tarkistusta tehdessä. Työ koetaan kuitenkin sujuvammaksi hyväksymällä vaara, minkä vuoksi muutosta työtapoihin ei ole tullut. Toisaalta myös tottumus pitää vanhassa työtavassa, vaikka vaara tunnetaan ja vaihtoehtoinen toimintatapa olisi mahdollinen. Vastaava ristiriita turvallisuuden ja työn sujuvuuden välillä tulee usein esiin myös, kun suojuksen alla olevia koneen osia on korjattu. Korjaustyön jälkeen suoja jää helposti pellon pientareelle tai pajan nurkkaan, koska halutaan tarkkailla, kuinka kone toimii korjauksen jälkeen.

Tyypillistä näyttäisi olevan myös, että läheskään aina uusien koneiden hankkiminen ei tarkoita vanhojen koneiden poistumista käytöstä. Sen sijaan "vanhat systeemit jäävät kuitenkin nekin käyttöön, mutta huonommalle huollolle ja ylläpidolle”. Ajan hammas nakertaa pikkuhiljaa tilojen ja rakenteiden kuntoa. Se, milloin joku kone tai rakennus on vielä käyttökelpoinen ja milloin se on syytä korjata, ei ole erityisen selkeärajaista. Korjaamiseen ryhdytään usein vasta, kun kone tai rakennus on niin vikaantunut, ettei se enää ole käyttökelpoinen. Korjaamis- ja ylläpitoaktiivisuuteen vaikuttavat todennäköisesti monet eritasoiset asiat, esimerkiksi ammattitaito ja harrastuneisuus, käytettävissä olevat tilat ja työkalut, varaosien ja tarvikkeiden saatavuus ja taloudellinen optimointi ("kalusto kannattaa pitää kunnossa - ylläpito vaatii aikaa ja rahaa"). Niin sanottujen jäähdyttelevien tilojen yleinen argumentti on se, ettei enää koeta tarpeelliseksi panostaa ylläpitoon ja korjaukseen jne.

Ajassa tapahtuvien muutosten myötä toiminta ja tila eivät enää vastaa toisiaan. Tästä seuraa helposti vaaratilanteita, koska esim. riskiä pienentävät rakenteet puuttuvat tilan käyttötarkoituksen tai tavan muututtua. Vanhoissa rakennuksissa on usein käytetty paloherkkiä materiaaleja ja rakenteita, ja niissä on palon etenemistä edesauttavia rakenteita. Polttomoottorikäyttöisten koneiden säilyttäminen ja jopa tulitöiden tekeminen tällaisissa, muusta käytöstä vapautuneissa tiloissa on kuitenkin yleistä. Uusista koneista on poistettu turvakaaria, koska kone ei mahdu kulkemaan vanhassa navetassa. Työsuojelun toteuttamisen kannalta tämä on hyvin hankalaa, koska rakennuksen elinkaari on pitkä ja käyttötarkoitus vaihtelee. Muutostyöt olisivat kalliita ja työläitä: "ja kumminki maatilalla on siis niin paljon niitä vaaranpaikkoja, että jos kaiken pistäs toimeen, niin se tuntus mahottomalta".

Koneiden ja rakennusten huolto- ja korjaustyöt, joiden turvallisuuteen tässä tutkimuksessa keskityttiin, vaativat usein erikoisosaamista, kuten rakennussuunnittelun tai sähkö- ja konetekniikan tuntemusta. Esimerkiksi turvallisten kulkuteiden ja työtasojen suunnittelu ja toteutus monimuotoisiin tiloihin, ei ole aivan helppoa ja toteutusta lykätään. "On jo pohdittu korjaamista, mutta vaikeahko rakentaa, raudasta pitäisi rakentaa...aika ahdas paikka, että siellä ei oikein tilaa rakentaa..” Ratkaisuja on useimmiten olemassa useita erilaisia, mutta niitä ei välttämättä tulla ajatelleeksi. Eräs henkilö kertoi: "Työturvallisuus on huomioitu sikalan vesisäiliön kohdalla hyvin. Koska vesimäärää ei näe muuten kuin kiipeämällä säiliön päälle, on säiliön sivuun tehty kiinteät kaiteet ja portaat (tikkaat) raudasta.". Tässä on pyritty parantamaan työturvallisuutta ja tilanne onkin varmasti kohentunut, mutta toisaalta olisi varmasti voinut helposti kehittää sellaisenkin ratkaisun, että vesimäärän saisi tarkistettua kiipeämättä.

Turvallinen työtapa saattaa monesti edellyttää ammattitason varusteita, esimerkiksi työstöalustoja, suojaimia jne. ”...Työympäristö on vaarallinen ja isännältä puuttuu turvakengät tai saappaat. Moottorisaha voi helposti sahautua jalkaan tai reiteen...”. Omatoimirakentamisessa riskit helposti kumuloituvat. Vastaava mestari voi nimellisesti olla joku sukulainen, itsellä ei ole riittävästi tietoa ja osaamista, kustannuksissa yritetään säästää, työllä on kiire, tehdään pitkiä päiviä, koska normaalitkin työt on hoidettava. Rakennusta edistetään väsyneenä aina muiden töiden lomassa. ”...on tosi kiire, kumminki olosuhteiden pakosta on jouduttu lisäämään elukoita ja pidetty niitä väliaikasissa ratkaisuissa ja hankittu myös peltoa ja on toi navetan rakennus ni on koko kesä tehty varmaan 15 tuntista päivää, väsymys painaa kaikkia..”

Maatilalla tapahtuvalle korjaustyölle on tyypillistä, että toimitaan tiedon, taidon, ajan, materiaalien ja työkalujen suhteen käytettävissä olevien resurssien varassa, eikä niinkään lähdetä etsimään optimiratkaisua esimerkiksi materiaalien suhteen. Ratkaisu tehdään toisin sanoen niillä tarvikkeilla, joita sattuu olemaan. Monesti tehty ratkaisu ajatellaan väliaikaiseksi "tehdään siihen sitten kunnon portaat myöhemmin", mutta väliaikaisilla ratkaisuilla on koehenkilöiden mukaan vahva taipumus jäädä pysyviksi. Eikä kerran tehtyä ratkaisua ryhdytä helposti uudestaan työstämään, vaikka sen turvallisuustaso olisikin heikko. 
Taustalla vaikuttavat myös turvallisuusasenteet. Ne vaihtelevat luonnollisesti henkilöittäin ja tiloittain. Mielenkiintoinen havainto oli, että myös esteettinen arvo voi hyvin ohittaa työturvallisuuden. Esimerkiksi vanha turvakaareton traktori haluttiin säilyttää käytössä entisellään koska sitä haluttiin esitellä tilalla käyville vieraille.

Asioiden priorisoinnilla on suuri vaikutus siihen, minkälaiseksi työympäristö muodostuu. Voi olla, että esimerkiksi uutena hankittuun kuivuripakettiin ei kuulunutkaan asialliset kulkutiet tasolta toiselle, vaan ne on sovittu tai jätetty viljelijän omatoimisesti rakennettavaksi. Paketti on tällöin vain laitepaketti, ja siten työturvallisuusmielessä toiminnallisesti puutteellinen kokonaisuus. Tällöin jää täysin viljelijän ammattitaidon, resurssien ja turvallisuushakuisuuden varaan, minkälaiseksi liikkuminen muodostuu. Suunnitellaanko ja toteutetaan tilaan turvalliset kulkutiet vai tyydytäänkö väliaikaisratkaisuna pariin lankkuun? Tuotantotoiminnan kannalta keskeiseksi koetut rakenteet tehdään, mutta turvarakenteet saatetaan jättää pois, vaikka vaara olisi huomattava. "Viljasiilon yläosassa olevalla kävelysillalla on suuri vaara pudota, koska kaiteita ei ole.

\section{Katalyytit eli työturvallisuustiedon hyödyntämistä edistäviä tekijöitä}

Myös työturvallisuustiedon hyödyntämistä ja tilan työturvallisuuden kehittymistä edistäviä tekijöitä tunnistettiin. Yksi nimettiin "auktoriteettikanavaksi”: Kun viesti tulee oikealta/arvostetulta henkilöltä, niin sillä näyttäisi olevan enemmän painoarvoa. Tällaisina henkilöinä joissakin kommenteissa näyttäytyivät esimerkiksi palopäällikkö, rakennustarkastaja tai arvostettu työntekijä.

Toinen selvästi tunnistettava katalyytti oli havahtuminen jonkin tapahtuman tai informaation seurauksena. Tällaisia esimerkkejä olivat muun muassa itselle tai naapurille sattunut paha tapaturma tai läheltä-piti tilanne ja opiskelupaikassa nähdyt dokumentit: ”...ja siinä on myös semmonen kun naapuri kun oli katsomassa jotain puimuria ni kompastu siellä ja oli pari kuukautta sairaalassa. Tuli jotain tosi pahoja tulehdushommia, ni se jotenkin huomattiin ja alettiin itekin siivota ettei tuu itelle mitään kompastumisia." "Joskus kun katottiin täällä koulussa netissä joku animaatioa kun jotain oli sattunut, niin näytin sen miehelle, ja sen jälkeen se kyllä korjas jonkun jutun”.

Läheltä-piti tilanteiden arvo nähtiin siinä, että ne paitsi kertovat tapaturmavaarasta niin ne myös tuottavat tarkentavaa informaatiota siitä mitä ja miten pitäisi korjata tai muuttaa. Koulutus nähtiin tärkeänä vaikuttajana työtapojen muotoutumiseen. Toisaalta myös nähtiin työtapojen lopulta sopeutuvan olosuhteisiin, tapoihin ja perinteisiin, vallitseviin asenteisiin ja muun tilanväen työn ja näkemyksen kunnioittamiseen. Ammattitaidon kehittymisen myötä kehittyy myös kyky suhteuttaa asioita ja valita järkeviä toimintatapoja: "On hyvä muistaa, että ihmisen teho on noin $50 \mathrm{~W}$ ja koneen 100x tai 1000x eli minun juoksemiseni ei auta tilanteen korjaamiseen".

Innostus muutoksiin ja työturvallisuuden kehittämiseen voi tulla harrastuksen tai vapaaehtoistyön kautta. Esimerkiksi vapaapalokuntalaisuus kehittää kykyä tunnistaa palo-, häkä- tai räjähdysvaaraan liittyviä tekijöitä. Palotilojen haastatteluissa todettiin, että "toisen tilalta on helppo sanoa, mitä pitäisi tehdä tai korjata”. Työsuojeluinterventioita pohdittaessa ja suunniteltaessa kannattaisikin hyödyntää vertaisryhmiä. Toisaalta paloturvallisuutta tai työturvallisuutta voidaan toki edistää myös velvoitteiden avulla: esimerkkinä voidaan mainita uusiin rakennuskohteisiin vaadittava pelastussuunnitelma.

Mielikuvaharjoittelua kuvailtiin yhtenä tapana työsuojelun kehittämisessä ja valmistautumisessa toimimaan kriisitilanteessa. Eräs viljelijä kertoi, että he ovat itse kuvitelleet erilaisia onnettomuustilanteita ja miettineet kuinka niissä toimittaisiin. Mielikuvaharjoittelu on voimakas ennaltaehkäisevä toimintamalli ja sen käyttöä tulisi edistää neuvonnassa ja koulutuksessa.

\section{Johtopäätökset}

Käyttäjälähtöisyyden on selkeästikin oltava kaiken työsuojelutoiminnan lähtökohta. Tämä koskee kaikkea työsuojeluun tähtäävää toimintaa interventioaiheiden valinnasta tehokkuuden seurantaan asti. Oikealla asialla oleminen ja perusteltu tieto työympäristön riskitekijöistä sekä siitä, millä toimenpiteillä työ voidaan saada turvallisemmaksi, eivät riitä. On keskeisen tärkeää tuntea myös se konteksti, johon työsuojeluun tähtäävä impulssi suunnataan. Tämän kontekstin osia ovat tämän tutkimuksen mukaan ainakin se, mitä kautta, millä tavoin ja missä tilanteessa tietoa herkimmin omaksutaan ja sovelletaan. On tiedettävä, mitkä tekijät kulloisessakin parannuskohteessa ovat keskeisiä muutokseen kannustavia ja toisaalta sitä ehkäiseviä tekijöitä. 
Kaiken kaikkiaan käytännöstä lähtevien esimerkkien avulla on helpompi kehittää tai luoda uusia ratkaisuja työsuojeluinterventioihin. Tämän tutkimuksen lähestymistapa koettiin tässä mielessä hedelmälliseksi; se tuotti viljelijöiden pohdintoja ja kokemuksia heidän oman työympäristönsä muodostumisesta. Näistä voidaan lähteä edelleen syventämään yksittäisiin ongelmakokonaisuuksiin, esimerkiksi rakentamisen turvallisuuteen. Haasteet ovat hankalia, mutta eivät mahdottomia.

Tapaturmien ja ammattitautien vähentämiseen tähtäävät hyvät aikeet kohtaavat maatilalla monia haasteita. Näistä keskeisin lienee ihmisten ja tilanteiden erilaisuus. Lähes kaikki parannukset kuitenkin edellyttävät viljelijän/tilanväen päätöstä ryhtyä toimenpiteisiin. Tarvitaan riittävä impulssi, joka muuttaa prioriteetteja siten, että päätös syntyy ja myös muuttuu toiminnaksi. Aina ei kyse edes ole suuresta taloudellisesta tai ajallisesta uhrauksesta, vaan vaikkapa "periytyneiden" tottumusten muuttamisesta ja työn uudelleenorganisoinnista. Tässä kohtaa voisi olla hyödyllistä miettiä, minkälaiset mielikuvat voisivat saada aikaan oikean suuntaisia muutoksia.

Investoinnit uuteen tekniikkaan, koneisiin, laitteisiin ja rakennuksiin, luo aina mahdollisuuden parantaa työsuojelun tasoa. Konedirektiivin mukaiset laitteet ovatkin periaatteessa läpikäyneet riskikartoituksen tyypillisen käytön ja myös väärinkäytön osalta. Viljelijän vastuulle jää kuitenkin uusien koneiden oikea (turvallista käyttöä koskevien ohjeiden mukainen) asennus ja käyttö sekä huolto- ja korjaustoimenpiteet. Haasteena tekniikan kohdalla onkin se, kuinka vanhentuva ja osittain korvattu, mutta edelleen käyttöön jäävä kalusto saataisiin samojen turvallisten käyttötapojen piiriin. Uusia, hyviä ratkaisuja voisi yrittää käyttää "astinlautana” myös heikompien kohteiden turvallisuuden kehittämiselle.

Rakennetun ympäristön turvallisuuden parantaminen voi olla kallista ja työlästä, eikä kerran tehtyä ratkaisua muutenkaan helposti lähdetä muuttamaan. Jonkinlaisena ratkaisuna voisi toimia esimerkiksi kriittisyysarviointi vaaranpaikkojen poistamisessa tai riskin pienentämisessä. Eli yritettäisiin tunnistaa pahimmat ongelmat ja poistaa ne tai ainakin pienentää riskiä esimerkiksi rakennuksen käyttötarkoituksen muuttuessa. Vertaisryhmillä voisi tässä olla annettavaa, samoin esimerkiksi pelastusviranomaisilla. Annetun avun pitäisi tuottaa konkreettisia, käytännöllisiä ratkaisuja. Vaikka viljelijät monesti eri syistä hyväksyvät työssään hankalankin työympäristön, niin monet kuitenkin arvostavat työmukavuuden ja tehokkuuden parantumista.

\section{Kiitokset}

Tutkimuksen päärahoittajat olivat Maatalousyrittäjien eläkelaitos ja Maatalouskoneiden tutkimussäätiö. Kiitokset lisäksi Seinäjoen ammattikorkeakoululle yhteistyöstä.

\section{Kirjallisuus}

Anyaegbunam, C. 2007. Social Marketing of Agricultural Safety and Health to Ageing and Limited ResourceFarmers: What are the Implications? Paper presented at Agricultural Safety \& Health Network Conference, Indianapolis, IN on March 6-8, 2007.

Available at http://www.agsafetyandhealthnet.org/AgeingFarmers_SocialMarketing.pdf

DeRoo, A. \& R.H Rautiainen. 2000. A Systematic Review of Farm Safety Interventions. American Journal of Preventive Medicine 18: 51-62.

ERKKI-tietopankki. Maatalouden ergonomiaratkaisut. Työterveyslaitos. Saatavissa: http://www.ttl.fi/ Mattelmäki, T. 2006. Design probes. Publication Series of the University of Art and Design Helsinki A 69. Vaajakoski, Finland: Gummerus printing. 219 s.

Murphy DJ. 1992. Safety and health in production agriculture. ASAE, Michigan, USA.

NASD. 2009. National Agricultural Safety Database. Saatavissa: http://www.cdc.gov/nasd/ Accessed April 28, 2009.

Nielsen, J. 1993. Usability Engineering. USA: Academic Press.

Rautiainen, R.H., M.M. Lehtola, L.M. Day, E. Schonstein, J. Suutarinen, S. Salminen \& J. Verbeek, 2008. Intervention for preventing injuries in the agricultural industry (Review). The Cochrane Collaboration. Issue $1 / 2008$.

Schulte P.A., A. Okun, C.M. Stephenson, M. Colligan, H. Ahlers, C. Gjessing, G. Loos, R.W. Niemeier, M.H. Sweeney. 2003. Information dissemination and use: critical components in occupational safety and health. American Journal of Industrial Medicine 44(5):515-31. 